\title{
Giant Antrochoanal Polyp: A Case Report
}

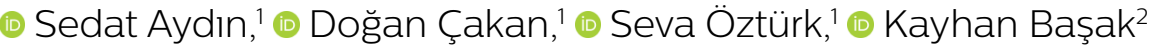

\author{
${ }^{1}$ Department of Otolaryngology, \\ Heath Sciences University Kartal Dr. \\ Lütfi Kırdar Training and Research \\ Hospital, İstanbul, Turkey \\ ${ }^{2}$ Department of Pathology, Heath \\ Sciences University Kartal Dr. Lütfi \\ Kırdar Training and Research \\ Hospital, İstanbul, Turkey \\ Submitted: 01.07.2018 \\ Accepted: 05.11.2018 \\ Correspondence: Sedat Aydın, \\ SBÜ Kartal Dr. Lütfi Kırdar Eğitim ve \\ Araştırma Hastanesi, KBB Kliniği, \\ İstanbul, Turkey \\ E-mail: sedataydin63@yahoo.com

arsing \\ Keywords: Antrochoanal \\ polyp; endoscopic sinus \\ surgery; maxillary sinus; nasal \\ obstruction; obstructive \\ sleep apnea.
}

\begin{abstract}
An antrochoanal polyp (ACP), also known as Killian's polyp, is a solid, benign, polypoid lesion originating from the inflammatory mucosa of the maxillary sinus and extending into the nose, choana, and nasopharynx through the maxillary ostium. ACP is rare, and is usually seen in adults. Cystic fibrosis is an important risk factor in young patients. Although the etiology is not completely known, allergies and sinonasal disease play an important role. The condition is usually unilateral but may also be bilateral. A I3-year-old girl presented with nasal obstruction, snoring, and episodes of obstructive sleep apnea. Examination revealed an ACP. Endoscopic sinus surgery was performed with a transoral approach to remove a giant $A C P$ extending to the epiglottis.
\end{abstract}

\section{INTRODUCTION}

An antrochoanal polyp (ACP) is a rare, benign solitary lesion that constitutes approximately $4 \%$ to $6 \%$ of all nasal polyps. When nasal polyps are found in the pediatric population, however, ACP may represent as much as $33 \%$. Although its etiology is still not precisely known, some authors have indicated that allergies may play a role, while others have suggested that sinonasal disease is responsible. Patients typically present with complaints of unilateral nasal obstruction, nasal discharge, snoring, foreign body sensation, postnasal discharge, hyposmia, or headaches.

Nasal endoscopy and paranasal sinus computed tomography (CT) are the gold standard tools for diagnosis based on observation of soft tissue in the maxillary sinus antrum without bony erosion, which may extend through the natural or accessory ostium to the nasal cavity to the choana. Angiofibroma, mucocele, allergic fungal rhinosinusitis, inverted papilloma, olfactory neuroblastoma, and meningoencephalocele are considered in the differential diagnosis. ${ }^{[1,2]}$

Presently described is the case of a 13-year-old girl who presented at the outpatient clinic with complaints of nasal obstruction and respiratory arrest during sleep. This was a very unusual case of a large $\mathrm{ACP}$ in a child.

\section{CASE REPORT}

A I3-year-old girl presented at the Ear, Nose, and Throat department with complaints of left-sided nasal obstruction, difficulty in swallowing, snoring, and occasional respiratory arrest. Her family stated that these complaints had become even more evident over the previous 2 months. There was no history of allergies. Examination with a tongue depressor revealed a large, soft, pale-pink polypoid lesion in the oropharynx behind the soft palate extending to the hypopharynx and the upper edge of the epiglottis (Fig. Ia).

A flexible nasopharyngoscopic examination of the polypoid tissue indicated that it originated from the left middle meatus, partially occluded the left nasal passage, and completely obscured the choana. In the differential diagnosis, cystic fibrosis (CF) was excluded using the sweat test. Paranasal sinus CT revealed a completely occluded maxillary sinus and a soft tissue mass extending from the soft palate to the hypopharynx (Fig. Ib).

Magnetic resonance imaging (MRI) with contrast demonstrated enhancement in the periphery of the maxillary sinus antrum without any enhancement in the central portion. Functional endoscopic sinus surgery (ESC) was performed under general anesthesia after receiving informed 

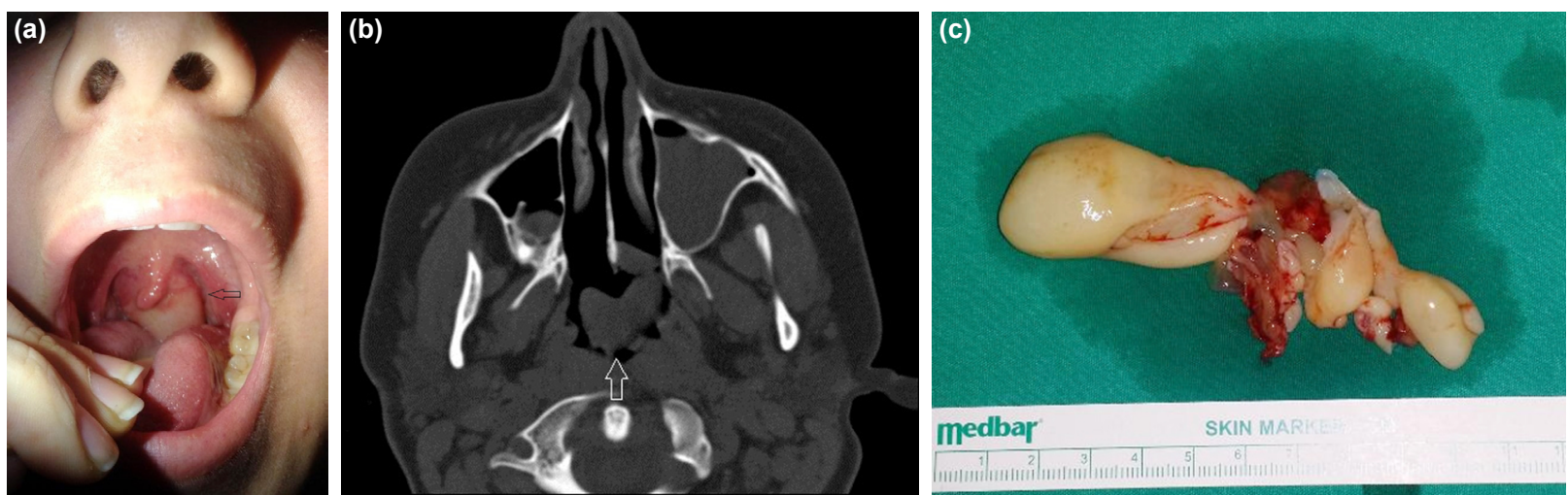

Figure 1. (a) Antrochoanal polyp (pale pink arrow) extending to the back of the tongue root, and completely filling the back of the patient's uvula and soft palate. (b) Computed tomography axial section illustrating a mass of soft tissue density (arrow) filling the left maxillary sinus antrum, passing behind the uvula, and extending to the hypopharynx. (c) A photo of an approximately 10-cm antrochoanal polyp specimen.

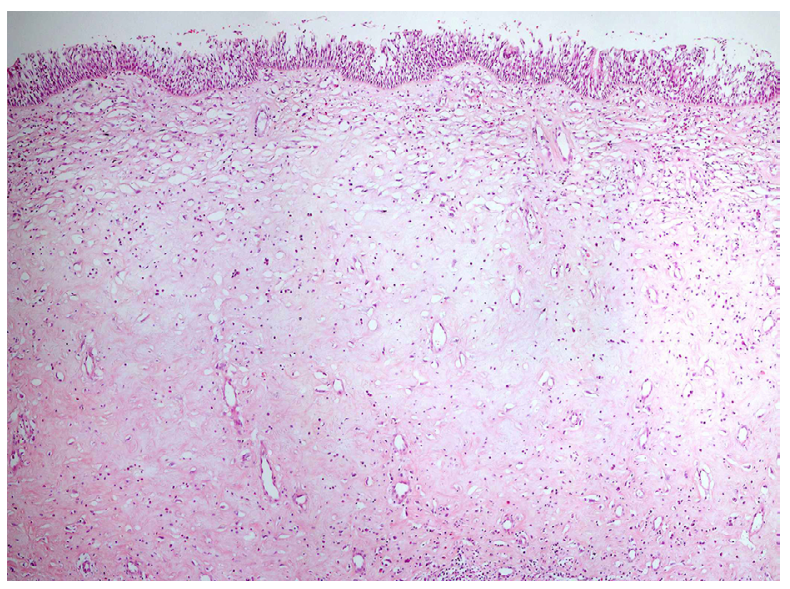

Figure 2. A respiratory-type polyp, with pseudostratified and ciliary columnar epithelium and dilated capillaries on the surface and inflammatory cells in the edematous stroma (H\&E; x200).

consent from the patient's family. It was determined that the polyp peduncle arising from the accessory ostium originated from the posterior wall of the maxillary sinus.

After aspiration of the mucoid fluid in the antrum, the tissues between the natural and accessory ostia were excised to form a common ostium. A giant sinus ostium was constructed after the giant ACP was freed from the nasal tract during ESC and removed via the transoral route (Fig. Ic). A small amount of sinus packing was put in place and removed 2 days after the operation. Histopathologically, a sample with pseudostratified and ciliary columnar epithelium with dilated capillaries on the surface was reported as polypoid tissue containing fibrosis and inflammatory cell infiltration in the edematous subepithelial stroma (Fig. 2 ). The patient was discharged 3 days after the operation without any complaints. No recurrence was observed at the postoperative $6^{\text {th }}$ month follow-up.

\section{DISCUSSION}

Professor Gustav Killian first described this polyp in 1906, and an ACP is also referred to as Killian's polyp. An ACP is formed by hypertrophy of the posterior wall of the antrum mucosa of the maxillary sinus occurring for unknown reasons, and the lesion may extend through the natural or accessory ostia of the sinus into the nasal cavity, choana, and nasopharynx. Macroscopically, usually the intramaxillary (antral) component is cystic, while the nasal and chiral component is solid.

In our 13-year-old patient, it was observed that the polyp extended outward through the accessory ostium of the maxillary sinus into the nasal cavity, and medially from the middle turbinate into the choana. Furthermore, it was visible behind the uvula up to the hypopharynx. A search of the literature suggests that this was a rare case in a pediatric patient. This type of polyp is most often reported in adults, though under 40 years of age..$^{[1,3,4]}$

The etiology is still not fully understood. There are studies indicating that chronic rhinosinusitis, or some inflammatory mediators, such as histamine, immunoglobulin $E$, adhesion molecules, platelet-activating factors, or metalloproteinases may be responsible. If an ACP is observed in a child, CF should be considered in the differential diagnosis. A sweat test in our case was negative, and no evidence was found to indicate $\mathrm{CF}^{[4]}$

Unilateral nasal obstruction is the most common complaint seen in ACP patients. Other complaints include nasal discharge, epistaxis, post nasal discharge, and snoring. However, as in our case, a bulky ACP extending to the level of the hypopharynx and the epiglottis can create serious problems, ranging from respiratory distress to difficulty in swallowing. Such patients require immediate surgical intervention. Although ACPs are most often unilateral, bilateral cases have also been reported in the literature. ${ }^{[5-9]}$

Endoscopic examination and CT are the gold standard diagnostic tools. However, in the pediatric age group, contrast-enhanced MRI is necessary to detect pathologies such as angiofibroma, encephalocele, and meningoencephalocele. CT and MRI with contrast have positively indicated $A C P^{[10,11]}$ High recurrence rates have been observed related to nasal polypectomy and Caldwell-Luc 
operations. As in our case, when there is an ACP that extends into the nasal cavity through the accessory maxillary ostium, the tissue between the natural and accessory ostia should be removed and the area should be opened. Although it is possible to excise ACPs mostly through the nasal passages, in addition to transnasal intervention, it is possible to excise the polyp via the transoral route in instances when it is large in size, as in our case.

When local anesthesia is preferred in elderly patients with an ACP extending to the level of the epiglottis, a silk suture passed to the distal end of the ACP in the hypopharynx may prevent the polyp from escaping into the larynx. ${ }^{[12]}$

\section{CONCLUSION}

We should also keep ACP in mind in the differential diagnosis of children presented with unilateral nasal obstruction. We must remember that this pathology, which can easily be recognized endoscopically in children and young adults in our routine ENT practice, may also involve the hypopharynx and the epiglottis, as in our case, and may lead to snoring and episodes of obstructive sleep apnea. It is the opinion of the authors that ESC should not be delayed in such cases.

\section{Informed Consent}

Written informed consent was obtained from the parents of the patient for the publication of the case report and the accompanying images.

Peer-review

Internally peer-reviewed.

Authorship Contributions

Concept: S.A., D.Ç.; Design: S.A., K.B.; Data collection \&/ or processing: D.Ç., S.Ö., K.B.; Analysis and/or interpreta- tion: S.A.; Literature search: S.A., S.Ö., K.B.; Writing: S.A.; Critical review: S.A.

Conflict of Interest

None declared.

\section{REFERENCES}

1. Maldonado M, Martínez A, Alobid I, Mullol J. The antrochoanal polyp. Rhinology 2004;42:178-82.

2. Chung SK, Chang BC, Dhong HJ. Surgical, radiologic, and histologic findings of the antrochoanal polyp. Am J Rhinol 2002;16:71-6.

3. Yaman H, Yllmaz S, Karali E, Güçlü E, Öztürk O. Evaluation and management of antrochoanal polyps. Clin Exp Otorhinolaryngol 2010;3:110-4.

4. Orvidas LJ, Beatty CW, Weaver AL. Antrochoanal polyps in children. Am J Rhinol 2001;15:321-5.

5. Çetinkaya EA. Giant antrochoanal polyp in an elderly patient: case report. Acta Otorhinolaryngol Ital 2008;28:147-9.

6. Kodur S, Siddappa SM, Shivakumar AM. Giant Antrochoanal Polyp-A Rare Presentation. J Clin Diagn Res 2017;11:MD01-02.

7. Öner F, Sakat MS, Gözeler MS, Altaş E, Üçüncü H, Kılıç K. Bilateral Antrochoanal Polyp. J Craniofac Surg 2015;26:e661-2.

8. Yılmaz YF, Titiz A, Özcan M, Tezer MS, Özlügedik S, Ünal A. Bilateral antrochoanal polyps in an adult: a case report. B-ENT 2007;3:97-9.

9. Salib RJ, Sadek SA, Dutt SN, Pearman K. Antrochoanal polyp presenting with obstructive sleep apnoea and cachexia. Int J Pediatr Otorhinolaryngol 2000;54:163-6.

10. De Vuysere S, Hermans R, Marchal G. Sinochoanal polyp and its variant, the angiomatous polyp: MRI findings. Eur Radiol 2001;11:55-8.

11. Yuca K, Bayram I, Kıroğlu AF, Etlik O, Çankaya H, Sakin F, et al. Evaluation and treatment of antrochoanal polyps. J Otolaryngol 2006;35:420-3.

12. Spadijer-Mirković C, Perić A, Vukomanović-Đurđević B, Stanojević I. Clinical case report of a large antrochoanal polyp. Acta Medica (Hradec Kralove) 2014;57:78-82.

\section{Dev Antrokoanal Polip: Olgu Sunumu}

Antrokoanal polip (AKP) aynı zamanda Killian' polibi olarak ta bilinir. İyi huylu, solid polipoid lezyon olup maksiller sinüsün enflamatuvar mukozasından kaynaklanır ve maksiller ostium vasıtasıyla burun içine, koanaya ve nazofarenkse uzanabilir. Antrokoanal polip nadir görülmekle birlikte çocuklarda daha da nadirdir ve kistik fibrozis, çocuklarda önemli bir risk faktörüdür. Etiyolojisi tam olarak bilinmemekle birlikte alerji ve sinonazal hastalık önemli rol oynar. Genellikle tek taraflı olup ancak nadiren iki taraflı görülebilirler. On üç yaşında AKP olan kız çocuğu bize burun tıkanıklı̆ı, horlama ve uykuda solunum durması nöbetleriyle başvurdu. Epiglota kadar uzanan bu dev AKP olgusunda transoral yol yardımıyla endoskopik sinüs cerrahisi uygulandı.

Anahtar Sözcükler: Antrokoanal polip; burun tıkanıklı̆ı; endoskopik sinüs cerrahisi; maksiller sinüs; uykuda solunum durması. 